\title{
The Institutional Arrangements in the Palm Oil Sector: Effort to Spur Economic Growth in Rural Areas
}

\author{
Almasdi Syahza \\ Universitas Riau, Riau
}

\begin{tabular}{|c|c|}
\hline ARTICLE INFO & A B S T RACT \\
\hline $\begin{array}{l}\text { Received: April 10, } 2011 \\
\text { Final revision: October 12, } 2011\end{array}$ & $\begin{array}{l}\text { Palm Oil is a fantastic plant for the people of Riau Province. It can } \\
\text { be seen from the rapid development of plantations, in } 2001 \text { palm oil }\end{array}$ \\
\hline $\begin{array}{l}\text { Keywords: } \\
\text { Institutional economics, } \\
\text { agroestate, } \\
\text { palm oil }\end{array}$ & $\begin{array}{l}\text { plantations covered an area of } 1,119,798 \text { ha and in } 2010 \text { it increased } \\
\text { to } 1,925,341 \text { ha with a growth of } 36.02 \% \text {. Palm oil plantation activities } \\
\text { brought economic impact on society, both for the people who } \\
\text { are directly involved with the activities of plantations and for their } \\
\text { surrounding community. To anticipate the rapid development, a model } \\
\text { avoiding inequality of income among farmers needs to be designed, } \\
\text { especially for self-supporting farmers in a partnership pattern. } \\
\text { Institutional model aims to increase the welfare of rural farmers in } \\
\text { the form of Palm Oil Based Agroestate (ABK). The concept of Palm } \\
\text { oil Based Agroestate collaborates between farmers, cooperatives, and } \\
\text { business enterprises. Through the ABK program, farmers will have an } \\
\text { opportunity to buy/have shares of the Palm oil Factory (PKS). There } \\
\text { are two main business activities of ABK model; first, business activities } \\
\text { that build palm oil plantations and factories of the derivative industry; } \\
\text { if necessary the settlement of participaing farmers will be established } \\
\text { by the developers; second, managing plantations and participating } \\
\text { farmers-owned factories as well as market the products carried out } \\
\text { by a business enterprise or a cooperative formed by the participant } \\
\text { farmers. }\end{array}$ \\
\hline
\end{tabular}

$\mathrm{T}$ he long-term development emphasizes economic development with the main objective to achieve a balance between agriculture and industry. To achieve this, the agricultural sector requires strength and ability to support its growth amidst the strong, more advanced industrial sector.
This can be seen from the development which had been designed during the New Order era in the form of five-year development plans I to $\mathrm{V}$, which focused on the agricultural sector. Since the reform era, the rural-based agricultural sector also has received considerable attention, resulting in the development 
of the agribusiness-based agricultural sector. The rural economic development is also accelerated through the increased production and the added value of the agricultural sector.

The economic development in Riau Province is based on two general patterns of development: the long-term general pattern and the short-term general pattern. The long-term general pattern includes the foundation of development with economic policy which is directed towards two key sectors, namely agriculture and industry sectors, by taking into account their relationship with other sectors. Specifically, the regional development policy in Riau Province is still focused on the key sectors. The direction of development is to stimulate regional economic growth and increase the contribution to GDP of Riau Province. According to the data from the Plantation Advisory Service (Dinas Perkebunan) in Riau Province (2010) in the 2005-2009 period, the growth in the agricultural sector was at $19.08 \%$ per year, while over the same period the plantation sub-sector grew by $18.97 \%$ per year. The significan growth in the plantation sub-sector was from the contribution of palm oil.

The people in rural areas have given a considerable attention to plantation crops. One reason is because there is a steady market for these plantation crops; meanwhile, the market for other plants outside the plantation sub-sector is very volatile. Especially, palm oil has been an excellent commodity in Riau that grows the interest of the people who are not part of the People's Nucleus Plantations (PIR) scheme from the lower class to the upper class in planting palm oil independently. Since the 1998 post-crisis time, the increase in the area of palm oil plantations in Riau has been dramatic, from 901,276 ha of plantations in 1998 to $1,119,798$ ha in 2001 . The area increased to $1,925,341$ ha in the late 2009. During the 19982009 period the average growth rate was $8.59 \%$ per year, while other commodities such as rubber and coconut suffered a decrease in the size of plantation areas. The increase in the plantation area and the production of palm oil during the last three years in Riau is presented in Table 1.

The activities of rural plantations have provided work opportunities for the people. The results of the research conducted by Almasdi Syahza (2009a) show that with the presence of plantation

Table 1. Increase in Plantation Area and Production of Palm oil in Riau Province in 2007-2009

\begin{tabular}{lccc}
\hline \multirow{2}{*}{ DISTRICT/CITY } & \multicolumn{3}{c}{ Size (Ha) } \\
\cline { 2 - 4 } & $\mathbf{2 0 0 7}$ & $\mathbf{2 0 0 8}$ & $\mathbf{2 0 0 9}$ \\
\hline Kampar & $291,475.50$ & $311,137.00$ & 316,282 \\
Rokan Hulu & $275,609.10$ & $262,673.60$ & 379,969 \\
Pelalawan & $177,906.01$ & $182,926.19$ & 183,400 \\
Indragiri Hulu & $114,582.00$ & $118,076.78$ & 118,538 \\
Kuantan Singingi & $121,854.36$ & $116,527.32$ & 122,731 \\
Bengkalis & $127,259.00$ & $147,643.50$ & 162,415 \\
Rokan Hilir & $148,879.00$ & $166,311.00$ & 206,173 \\
Dumai & $24,930.00$ & $27,954.00$ & 31,022 \\
Siak & $183,598.13$ & $184,219.48$ & 186,819 \\
Indragiri Hilir & $143,431.50$ & $148,729.50$ & 210,529 \\
Pekanbaru & $2,857.00$ & $7,353.00$ & 7,464 \\
\hline Total (ha) & $1,612,381.60$ & $1,673,551.37$ & $1,925,341$ \\
\hline Production (tons) & $5,119,290$ & $5,764,201$ & $5,932,310$ \\
\hline Source Regional Office of Plantations in Rian Province, 2011 & &
\end{tabular}

companies the livelihoods of the local communities are no longer limited to the primary sector in meeting their needs as now they could expand their livelihoods to the tertiary sector. Various sources of income are available for them as they can work as such as sellers (selling groceries, rubber, transportation ticket, and ice), employees (teachers, employees of the village government), workers in domestic industry (the industry of tofu, bread, and roof tiles), menial laborers, fishermen, timber seekers in the woods and carpenters.

For the people in rural areas, plantation crops have been an alternative source of income to improve the family's economy, so their interest in the development of plantations remains high. Palm oil cultivation is proved to contribute to the increase in the welfare of farmers in the rural areas. In regard to human activities, the development of plantations has also caused a high mobility of the population.

The development of palm oil plantations in Riau Province has created impact on the economic activities in rural areas. The results of the research conducted by Almasdi Syahza (2010) show that the farmers' income range from Rp3,475,029 to Rp $4,125,242$. If the assumed exchange rate of Rupiah against Dollar is US $\$ 1=$ Rp 9,000, the income of palm oil farmers range from US $\$ 4,633.37$ to USD $\$ 5,500.32$ per year. In addition, the development has impact on the acceleration of development of the people's economy which will help to reduce poverty in rural areas.

The rapid development of palm oil plantations lead to the emergence of centers of economic growth in rural areas surrounding the plantations. This increases the purchasing power of the rural communities, especially to buy the daily needs of the household and palm oil production facilities. However, the preparation of the development of plantations requires land. If this is not controlled by the policy makers, there will be conversion of land use in rural areas (Almasdi Syahza, 2011).
Based on the illustrations and the problems outlined above, the purpose of this research is to obtain information on the development of palm oil plantations in Riau and the solutions in terms of the institutional arrangements in the context of economic development in rural areas.

The research has managed to find a model for Institutional Arrangement of Palm oil in the Effort to Spur the Economy in Rural Areas. This design is expected to increase rural economic growth from both the plantation and non-plantation sectors. The results of this research can also be used to formulate which activities or strategies should be taken by the local government for future agricultural development and strategies for rural economic development.

\section{Theoretical Framework}

In Indonesia the agribusiness sector has the potential to compete and seize the marke opportunities in this free trade era. Outside the agribusiness sector, not only it is difficult to compete but also it is also challenging to empower the people's economy. The government policy which favors the development of the agribusiness sector at the macro level needs to be combined with efforts at the micro level to ensure that the benefits of the development can be enjoyed by society. Past experience shows that the major contribution of the agribusiness secto to the national economy was not followed by sufficient increase in farmers' income. Therefore to empower the people's economy, favorable conditions created for the the development of the agribusiness sector at national level should be combined with a mechanism which can ensure that the benefits of the development can be enjoyed by everyone.

One reason of the powerlessness of the rural people is the policy mismatch in the past, overlooking the agricultural sector as the basis for comparative and competitive advantages. Meanwhile, in fact the economic empowerment of the rural community 
does not only benefit the rural community, but it also builds Indonesia's economic strengths which is based on its comparative and competitive advantages (Yuswar Zainal Basri, 2003)

Income inequality between the rural and urban areas is quite considerable. The agribusiness is seen as the solution to remove this inequality. According to Lewis in Todaro Todaro, Michael P (2006), underdeveloped economy consists of two sectors, namely: 1) the traditional sector, or the rural subsistence sector which is overpopulated and is characterized by the marginal productivity of the labor which is equal to zero, 2) the modern urban industrial sector with its high productivity level which becomes a transition for workers who gradually move from the subsistence sector. Lewis assumed that the wage level in urban areas is 30 percent higher than the average income in rura areas, and this condition forces the workers to move from the village to the city.

Rural development should be able to reduce the disparity between rural and urban areas. One of the concepts put forward by Friedmann. J and Mike Douglass in Almasdi Syahza (2007b) is development of an agropolitan. The concept describe how to accelerate the development in rural areas using the potentials owned by the village itself. The following are the things which should be done: First, to change the rural areas by introducing elements of urban lifestyle (urbanism), which have been adapted to a particular rural environment. This will discourage migration from the rural to urban areas. Investment in rural areas is one way to reduce urbanization and to change rural settlements into a mixed entity which is called an agropolis or a city in the field; Second, to expand the social relations in rural areas beyond the village boundaries, thus forming a broader socio-economic and political space (an agropolitan district) Third, to reduce social dislocation in the development process by maintaining the family unity, increasing the sense of security, and providing personal satisfaction in building a new society; Fourth, to ensure steady revenues of villages and cities. The disparity is minimized by way of increasing productive work opportunities in rural areas, especially by combining the agricultural and non-agricultural activities in the same community; Fifth, to employ the existing workforce more effectively by directing the workforce to activities in the development of resources in each and every agropolitan district, including the increase in agricultural products; Sixth, to establish a network of agropolitan districts into a regional network by establishing and improving the relationship between agropolitan districts and cities; Seventh, to establish a government and a planning process which are adjusted to the rural conditions so that the priority in the development is created and its implementation on the local population is assured; Eighth, to provide financial resources to build an agropolitan.

According to Ginanjar Kartasasmita (1996), the development of rural areas needs to be carried out using the approach which is suitable to the nature and characteristics of the rural areas. Rural development should follow four major efforts, which are interrelated and form the main strategies, namely: First, to empower the economy of the rural people. The empowerment requires capital and guidance on the utilization of technology and marketing to empower and create independence of the rural communities; Second, to improve the quality of human resources in rural areas in order that they have an adequate basis to improve and strengthen their productivity and competitiveness; Third, to develop infrastructures in rural areas. Transportation infrastructure is an absolute requirement in these areas, since it will help villages to keep up with other more advanced villages; and Fourth, to build both formal and nonformal rural institutions. The institutional development required is the creation of good services especially to boost the rural economy such as financial institutions.

For thegovernment of Indonesia,ruraldevelopment has been associated with the development of agricultural sector which later is developed in the form of agribusiness. Agricultural development which has been developed on a large scale is the plantation sub-sector which generates excellent export commodities, including palm oil, rubber, gambier, and coconut. Bustanul Arifin (2001) states that the development of the agricultural sector in a broad sense should be directed to the system of agribusiness and agro-industry because this approach will increase the added value of the agricultural sector, which in fact can increase the income of local players or actors in agribusiness and agro-industry.

Agribusiness has a very important role in Indonesia's economy and in fact its degree of importance is expected to increase, especially after the sectors of mining and petroleum experience a particularly alarming decline in production. The agribusiness sector requires cooperation of various parties involved namely the government, private sector, farmers, and banking in order that this sector could contribute to the country's foreign exchange reserves. The policy on the increase in investment must be supported by the creation of favorable climate for investment in Indonesia, including in terms of bureaucracy, access to credit, and a review of taxation laws and tax rates for the agribusiness sector (Gumbira Sa'id, E. and L. Febriyanti, 2005).

The development of agricultural sector in a broad sense should be directed to the system of agribusiness and agro-industry since this approach will increase the added value of the agricultural sector, which substantially increases the income of the local players or actors in agribusiness and agro-industry. The results of the research conducted by Almasdi Syahza (2005) show other factors that support the prospects of future development of agribusiness, including: 1) the growing population which leads to the increasing needs for food, creating a good market opportunity for agribusiness; 2) the rising income which will improve the food quality and diversification.
Product diversification requires the processing of products (agro-industry), and 3 ) the developmen of agribusiness which will also have an impact on the economic growth of a region, increasing the farmers' income and in turn expected to reduce the disparity of the people's income.

Nevertheless, the future development of agricultural sector still encounters some obstacles, especially in the development of agricultura system which is based on agribusiness and agroindustry. The obstacles especially encountere by small-scale farmers, are among other thing (Almasdi Syahza, 2007a): 1) lack of capital structure and access to financial sources, 2), availability of land and soil fertility problems, 3) provision and distribution of production facilities, 4) limited mastery of technology, 5) lack of organization and management of agricultural business, and 6) low quantity and quality of human resources in the agribusiness sector. Farmers are human resource that play an important role in determining the success of agricultural activities since they are the workers and managers in the business.

To develop the economy in rural areas, the government of Riau Province have adopted a policy on the development of agricultural secto that is focused on the rural areas. For that purpose the local government have developed plantatio subsector as part of the agricultural sector, especially palm oil as the main commodity. There are several reasons why the government of Riau Province prioritizes palm oil: First, the physical and environmental conditions of the region permits the development of palm oil plantations; Second, the condition of soil in Riau allows the cultivation of palm oil trees which generate more yields than in other areas; Third, in terms of product marketing Riau Province has the advantage because of its close proximity to the international markets in Singapore; Fourth, Riau has become one the regions of development in West Indonesia upo the launching of Indonesia Malaysia Singapore Growth Triangle (IMS-GT) and Indonesia Malaysia 
Thailand Growth Triangle (IMT-GT), which means there are more profitable market opportunities, and Fifth, the results which have been gained show that palm oil generates higher income for farmers compared to other plantation crops (Almasdi Syahza, 2003).

In order to stimulate economic growth, the current economic policy should embrace a new paradigm in which the empowerment of people's economy should be a major concern. Since the livelihoods of most people are in the agricultural sector and the sector still makes a significant contribution to the country's economy, the empowerment of the people's economy also means building a bette agricultural economy. Industrial developmen should consider its backward linkage with the agricultural sector or the primary sector while its forward linkages should pay attention to the processing which increases the added value and to effective marketing so that that products are useful. The concept of agricultural development is referred to as the concept of agribusiness

In order to realize the objective to develop the people's economy, especially through the agricultural sector, it is necessary to prepare a strategic policy to increase or accelerate the growth of the agricultural sector, particularly to increase the income and improve welfare. One way to achieve this is by the development of agribusiness which is well planned and linked to the development of other economic sectors

\section{METHODS}

The research is conducted using a survey with a descriptive method (Descriptive Research). The purpose of a descriptive research is to capture in a systematic, factual and accurate manner the facts and characteristics of the population (palm oil farmers) in areas selected as the research sites.

The research was conducted in several sites in Riau Province which develop the plantation sub-secto particularly by growing palm oils. The sites were decided at random, although a special attention is given especially to the sites in which centers of economic growth emerge in rural areas as the impact of the development of palm oil plantations. The reasons for the site selection include: 1) the spatial plan of Riau Province, which means that the area is part of the center of development of plantation particularly palm oil plantation, 2) the age of palm oil in the survey area on the optimum production age which is 10 to 16 years (for production of FFB, palm oil and palm kernel), 3 ) on the areas of the development of plantations, there are two types of activities, namely: plasma palm oil plantations with state-owned enterprises as the core and palm oil plantations with private companies as the core, 4 ) in the surrounding areas of the palm oil plantations a lot of local people plant palm oils independently, and 5) the selected sites taken as samples have different level of plantation productivity.

Stratified Cluster Sampling was conducted to obtain samples which represent each of selected sites. This method was used based on the consideration that the research sites are scattered and the characteristics of people who are the object of study are diverse. In each selected cluster, two types of respondents were taken: the respondents who are plantation farmers and the respondents who are non-plantation farmers. The sample size in each stratum (the plantation farmers and the non-plantation farmers) is determined proportionally.

This research used the primary and secondary data. The required primary data include the identity of samples, land ownership and control, household income, diversification of business, business opportunities, and increase in employment. To complement the information, an interview of public figures in the research sites was conducted. The primary data was collected using a list of questions that had been prepared based on the needs of the research. The questionnaire serves as a general guideline to remind the researcher not to deviate from the purpose of the research. The accurate information was obtained by using the method of Rapid Rural Appraisal (RRA), which is a participatory approach to obtain data / information and a general assessment in a relatively short time. The advantage of this approach is that the research can cover a wider area in a relatively short period of time to obtain extensive information in general. In this RRA method the information collected is limited to the information required in accordance with the purpose of the research, but the data are more in-depth as the sources of the information are traced. This way, complete information about a particular thing can be obtained.

To reduce the bias which is caused by the subjective element of the researcher, a preliminary analysis was conducted each time an interview of the respondent was completed. If the analysis finds data errors or different data from what were expected due to misinformation or incorrect interpretation, the sources of information would be confirmed or the search for additional information would be obtained to complete the one available Based on the information from the site and the results of data analysis, a institutional model for development of palm oil plantation in rural areas is formulated in an effort to spur the rural economic growth

\section{RESULTS AND DISCUSSION}

\section{Development of Economic Institutional Mode}

in the Palm oil Sector

The rapid increase of the community plantation areas particularly those which are individually managed has created the need to design a model to prevent income disparity between plasma farmers and individual farmers. The model which is designed to increase the welfare of farmers in rural areas is the Oil Palm Based Agroestate (ABK). The model presented is intended to remove the dichotomies from the unfair distribution of profits between the (plasma and individual) farmers of palm oil and the core company and to ensure the development and sustainability of palm oil factories (PSK). The results of the research conducted by Almasdi Syahza (2010) show that the program for the development of palm oil plantations has been only limited to the community plantation (plasma) and the company plantation (nucleus). The farmers' ownership is only limited to the parcel of land which has been determined in the plasma program, while the factory which processes fresh fruit bunches (FFB) is owned solely by the company. In the future, it is necessary to consider a model of partnership for the development of palm oil plantations, in which the farmers have some form of ownership of the palm oil plantations and shares of the palm oil mil or factory. Farmers will buy a package consisting of a parcel of palm oil plantation and the factory's shares through a cooperative. In this program the farmers are given the opportunity to buy / own shares in the factory of the nucleus company.

The availability of quality, quantity and continuity o raw materials needs to be guaranteed to achieve the agro-industry, including palm oil industry. The link between the source of raw materials and the agro-industry of palm oil should be integrated into a form of ownership. This concept of partnership emphasizes the principle of joint ownership by farmers of the agricultural activities and the processing factory, which is managed by the farmers' cooperative.

This implementation is oriented to the welfare of farmers by putting the emphasis on efficiency in the processing of productive agricultural activities and increase in the added value in the contex of agribusiness with an institution designed within a working network based on the ability and professionalism of various different actor including the developers, industrial factories, settlement of participant farmers, active participan farmers, business entity for processing (BUP) or cooperative, or management (agricultura activities, industrial factories), and financing institutions. 
In the palm oil-based agroestate (ABK) model, there are two main business activities: first, the activities to establish plantations and industrial factories, and if necessary, to build the settlement of participant farmers that will be carried out by the developers, second, the business of managing the plantations and factories of the participant farmers and of marketing the yields which is carried out by an entity managing the business or a cooperative established by the farmers themselves. The palm oil-based agroestate (ABK) model is a concept in the development of the plantations in rural areas for the future, and this concept is one form of cooperation with the developer.

The above model is designed for the economic development in rural society which is based on agriculture (palm oil plantation). The model aims to build palm oil plantations for farmers who do not have their farmers who have land but do not own capital for developing their agricultural business. These farmers do not have adequate land as a source of their livelihoods nor do they have land to live a decent life to support their family. This model is also the development of the agropolitan concept as introduced by Friedman and Douglass (1976). The agropolitan concept is one strategy to accelerate the rural economic development.

In brief, the concept of Palm oil-Based Agroestate (ABK) model which involves the rural community (farmers who do not have plantations) is presented in Figure 1.

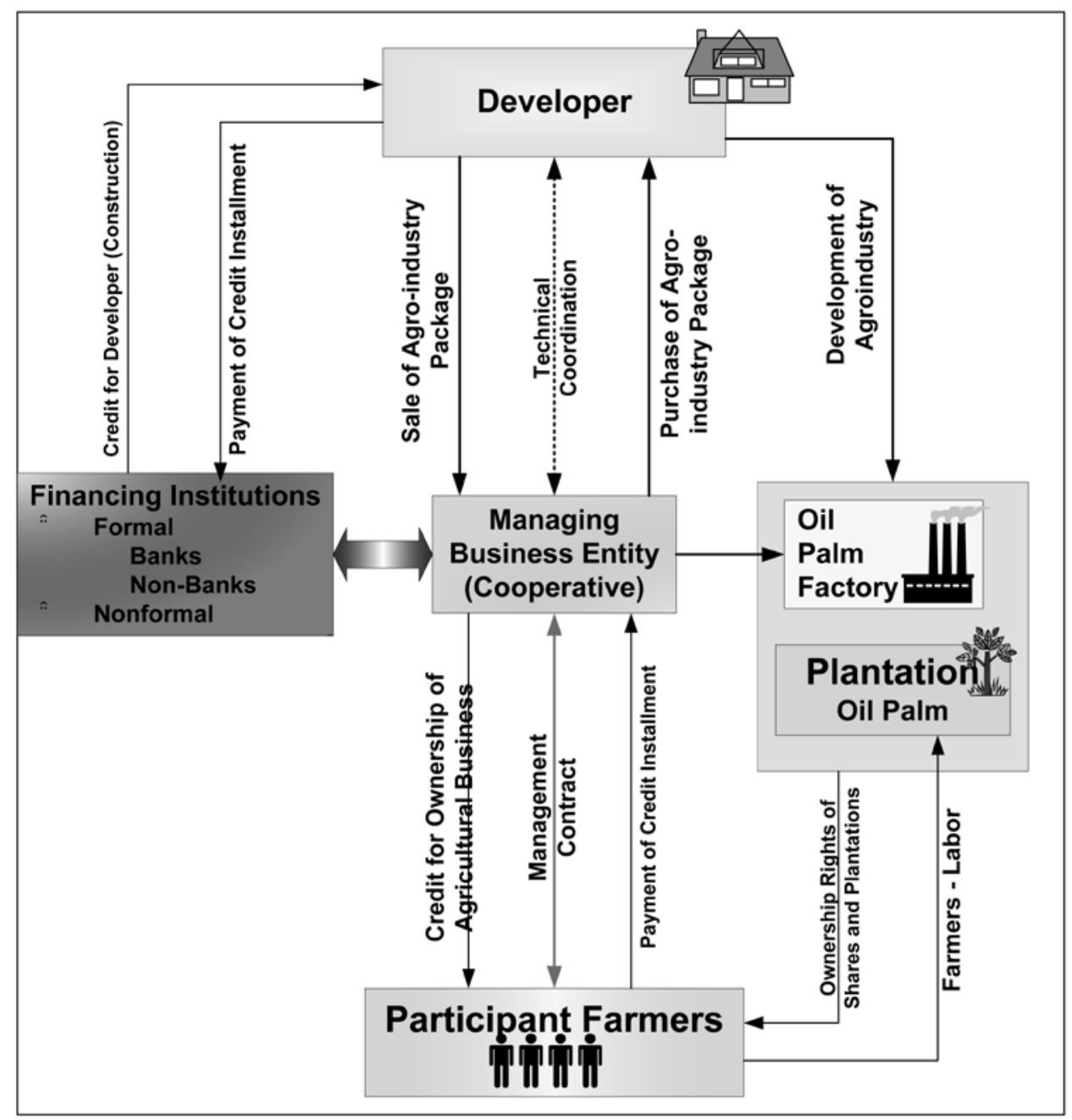

Figure 1. Conceptual Scheme of Palm oil Based Agroestate (ABK) model in Rural Areas (Almasdi Syahza, 2007b)

For more details, the model can be described as follows:

The developer establishes a plantation (agricultural activities) and a factory which processes the crops (agribusiness) until the plantation is ready to produce and the industrial factory is ready for operation. The developer can use its own sources of funding or loans from banks or other parties to establish the plantation and the factory.

- The plantation and the factory that have been established by the developer are sold in the form of units or shares to active farmers or farmers who are really interested in managing a plantation and the participants are the rural community. As the owner of the plantation, the participant farmers will receive a title deed as a proof of ownership of a parcel of the plantation and as a proof of ownership of the factory these farmers will receive shares.

- The participant farmers purchase a plot of plantationand the factory's shares using a credit facility provided by financing institutions. The availability of this credit scheme is facilitated by the developer or by the cooperative. The participant farmers as the owners of the plantation plots pay a management fee in the amount which is agreed on and specified in the contract of management. The company providing the management services will manage the plantation and the factory under the principles of plantation management and professionalism.

- The ownership of capital of the factory by participant farmers is limited to a maximum of $40 \%$ of its total working capital, while the rest is owned by the nucleus company and the local government. This is to maintain the professional management of the factory. The model of share ownership can be seen in Figure 2.

- In the management of plantations, active farmers are grouped into field farmers group (KPH or Kelompok Petani Hamparan) and are needed as workers who receive wages according to the agreement.

- The farmers' income is expected to be fairly large because it comes from various sources. Active farmers receive their income from the yields of their own plantations, wage a workers, and dividends from holding the shares of the factory. Another advantage is the continuity of raw material for the factory will be assured because these farmers fee that they own the factory, thus minimizing the possibility of them selling FFB to another factory

- The developer will return the capital use (its own funds and loan from the financing institutions) and will benefit from the yields of the plantation and shares of the industria factory which has been built.

For farmers in rural areas who have parcels of land to develop into palm oil plantations but do not have sufficient working capital for the development, $\mathrm{ABK}$ model with a partnership pattern is developed. In this partnership, the plantation development is carried out by using credit facilities from banks or non-bank financial institutions. The purpose is to establish and develop the community plantation in a new area or the existing areas with advanced technologies so that farmers can earn a decent income. This also creates a business management system called agribusiness by incorporating a variety of activities of production, processing, and marketing of products in an integrated manner.

ABK model with a partnership pattern is developed by companies engaged in the plantation busines which are designated as the nucleus company (partner) with the guidance and support of the local government agencies whose functions are relevant with the development of plantations. The partnership adopted in the development of plantation business by utilizing the credit facilitie is a nucleus partnership with the plasma farmers. In this partnership, farmers are represented by a cooperative that is established directly by farmers. The coordination of development of this plantation 
project or the ABK model with a partnership pattern is carried out by the Provincial and District Project Plantation Development Team established by the relevant Governor and Head of District. Thus, the partnership between the plantation companies and the cooperative becomes complete and sustainable.

This ABK Program provides participant farmers with the opportunity to hold shares of the palm oil factory. The procedure for share ownership can be arranged by the agreement between the farmers who in this case are represented by the cooperative and the government through the nucleus companies and related agencies. In this program it is recommended that the ownership of shares should involve three components, namely: farmers through a cooperative, the

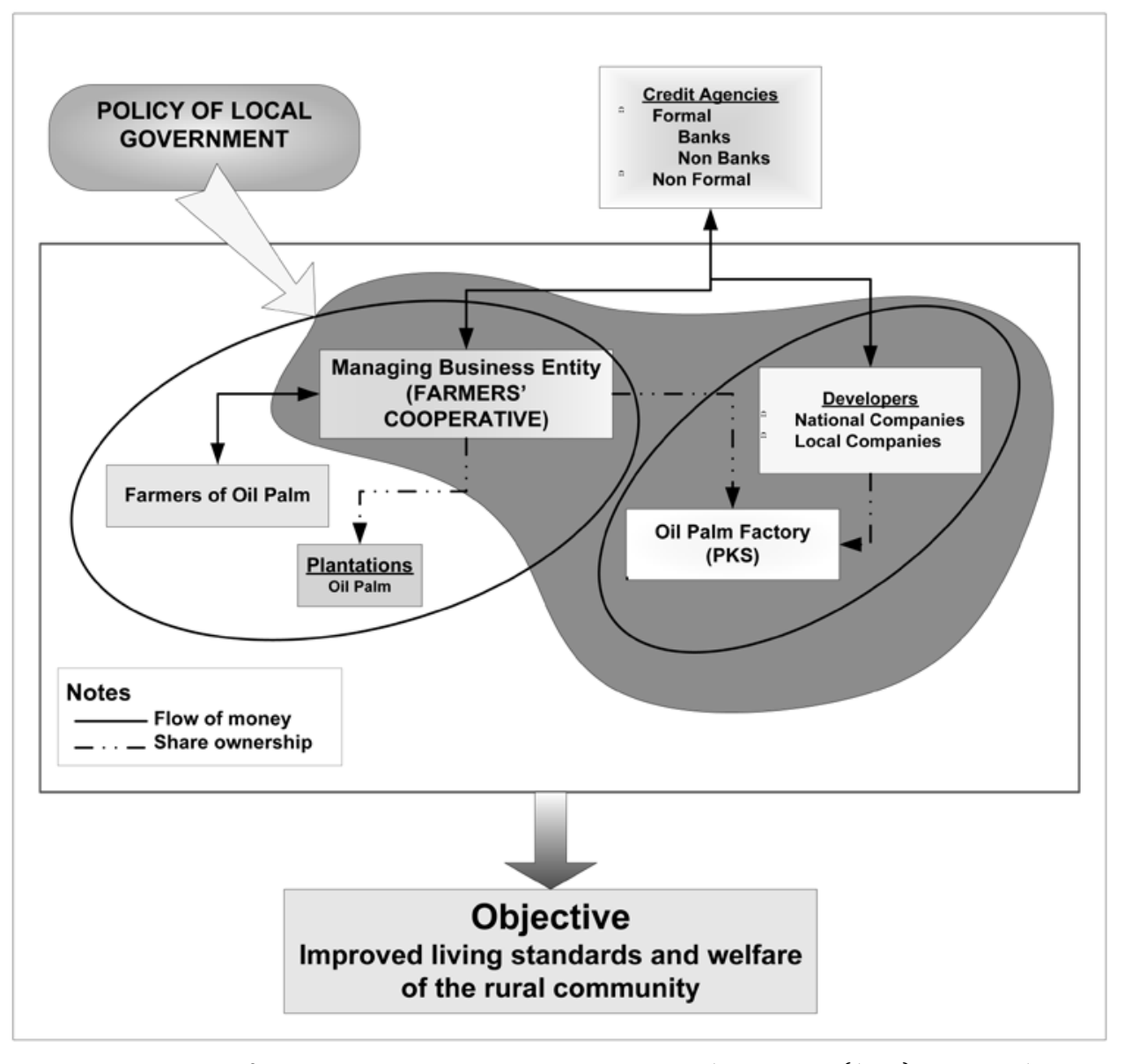

Figure 2. Design of Capital Ownership in Palm oil Based Agroestate (ABK) in Rural Areas (Almasdi Syahza, 2009c). nucleus company, and the local government. Meanwhile, the composition of share ownership can be arranged by the agreement of all three components. In addition, Setiadi Wijaya (2002) reveals the benefits of the cooperative are: 1) to help to improve the social and economic standards in the region by utilizing the potential and providing work opportunities 2) to give direct benefits, because a cooperative is suitable to the life of the rural community and 3) the rural economy can grow since a cooperative is firmly rooted in the rural areas.

The design of the capital ownership of the factory through ABK Program with a partnership pattern is also the same as the model of the capital ownership through the ABK program for new farmers as presented in Figure 2.
The empowerment of rural economy through the use of $A B K$ model with a partnership pattern should meet the following requirements

- Farmers who are participants of ABK with a partnership pattern are the local residents who own land and farmers whose land is affected by the development of KKPA palm oil plantations or who are not yet members of the cooperative.

- The preparation and determination of prospective participant farmers is carried out by the management of the cooperative with the acknowledgment of the head of village as the basis for the approval from the head of district.

- The prospective participant farmers are given the opportunity to participate in the development of plantations as workers.

- The participant farmers are entitled to palm oil plantation of a certain size in accordance with the cooperation agreement agreed between the farmers with the cooperative and the nucleus company.

- The participant farmers receive the proceeds from the sale of FFB after deduction for installment of loans and obligations to the cooperative.

- The participant farmers receive a certificate of ownership of the palm oil plantation after the loan is paid off.

- The farmers have the right require the accountability of the cooperative management for the plantation development at the meeting of members.

- The participant farmers must comply with and adhere to all the terms set forth in the establishment of ABK model with a Partnership pattern.

- The farmers are entitled to an opportunity to purchase shares of the palm oil factory which is built by the nucleus company.

The cooperation for development of palm oil in the rural areas with the involvement of the business players, the local government and the local community will reduce the socio-economic inequality in the rural areas. The local community will feel the impact of the plantation developmen through their engagement and increased income. Cooperation will create the purchasing power and demand for goods, thus increasing the mobility of goods in the rural areas. This condition will lead to improved living standards of rural society and the emergence of growth centers in the rural areas.

\section{Model of Credit Scheme provided by a Cooperative}

\section{for its Members (KKPA)}

A credit scheme provided by a primary cooperative for its members and called KKPA is the investment credit and working capital from Bank Indonesia or PT. Permodalan Nasional Madani for primary cooperatives to be channeled to their members to finance the members' productive business. One of the activities is the development of plantation with partnership model through the utilization of KKPA facilities. The purpose is to establish and develop the community plantations in a new area or the already existing areas with advanced technologies so that farmers can earn a decent income. It also creates a business management system that is agribusiness by incorporating a variety of activitie of production, processing, and marketing in an integrated manner.

The development of plantations with KKPA partnership pattern is carried out by plantation companies which are designated as the nucleus companies (partner) with the guidance and support of the local government agencies whose functions are relevant with the development of plantations. The partnership model adopted in the development of the plantation business by utilizing KKPA is a core partnership pattern with the plasma (farmers). In this partnership, the farmers are represented by a cooperative which is formed directly by the farmers themselves. The coordination of development of plantation projec called the ABK model with partnership pattern is carried out by the Provincial and District Project 
Plantation Development Team established by the relevant Governor and Head of District. Thus, the partnership between the plantation companies and the cooperative is complete and sustainable.

The development of plantation with KKPA pattern is based on the Decree of Governor of Riau Province No. 07 of 2001 on the procedures for palm oil development with a partnership pattern through the utilization of a credit scheme provided by a cooperative for its members which is called KKPA. The participants of KKPA program are the local farmers and members of the cooperatives that have land. Meanwhile, the cooperative which carries out the management is a primary cooperative as a business entity whose member are the community and has obtained its deed of establishment (being a legal entity) which is issued by the government.

KKPA Program provides the opportunities for participant farmers to hold shares of the factory. The procedure for share ownership can be arranged by an agreement between the farmers who in this case are represented by the cooperative and the government through the nucleus company and the related agencies. In this program, it is recommended that the share ownership should involve three components, namely: farmers through cooperatives, the nucleus companies, and the government. Meanwhile, the composition of share ownership can be arranged by the agreement of all three components. The design of the ownership of capital of the factory in KKPA program is the same as the capital ownership in a partnership for palm oil business that is presented in Figure 2.

\section{Participant farmers}

The participant farmers of KKPA program according to the Decree of Governor Number 07 of 2001:

- The participant farmers in KKPA program with a partnership pattern are the local residents who own land including farmers whose land are affected by the development of palm oil plantation utilizing KKPA and who are members of a cooperative.

The preparation and determination of prospective participant farmers is carried out by the management of the cooperative with the acknowledgment of the head of village as the basis for the approval from the head of district.

- The prospective participant farmers are given the opportunity to participate in the development of plantation as workers.

The participant farmers are entitled to palm oil plantation of a certain size in accordance with the cooperation agreement agreed between the farmers with the cooperative and the core company.

The participant farmers receive the proceeds from the sale of FFB after deduction for installment of loans and obligations to the cooperative.

The participant farmers receive a certificate of ownership of the palm oil plantation after the loan is paid off

The farmers have the right require the accountability of the cooperative management for the plantation development at the meeting of members.

The participant farmers must comply with and adhere to all conditions as determined in the establishment of plantation which uses the KKPA pattern.

- The farmers are entitled to an opportunity to purchase shares of the palm oil factory which is built by the core company.

\section{Farmers' Cooperative}

A farmers' cooperative that manages the community palm oil plantations is a primary cooperative which is established as a legal entity in accordance with Law No. 25 of 1992 on Cooperatives. In the implementation of partnership, the cooperative must first enter into an agreement for the development of palm oil plantations with the companies which are designated as partners and have the expertise in palm oil plantation. To obtain KKPA funds, the cooperative must submit a project proposal to the implementing bank through and/or in cooperation with the core company as a partner.

In order to increase the income of participant farmers, the cooperative should also foster its members in developing the supporting or additional crops, such as palawija crops, horticulture crops, etc. These crops become the source of income other than from the palm oil plantations for its members. In other words, if the price of FFB decreases, the farmers still have another source of income from the other activities. To provide motivation to the farmers, the cooperative must help to establish cooperation for the marketing of agricultural products with third parties. Figure 3 shows the form of business partners in the community plantations and the supporting plants in rural areas.

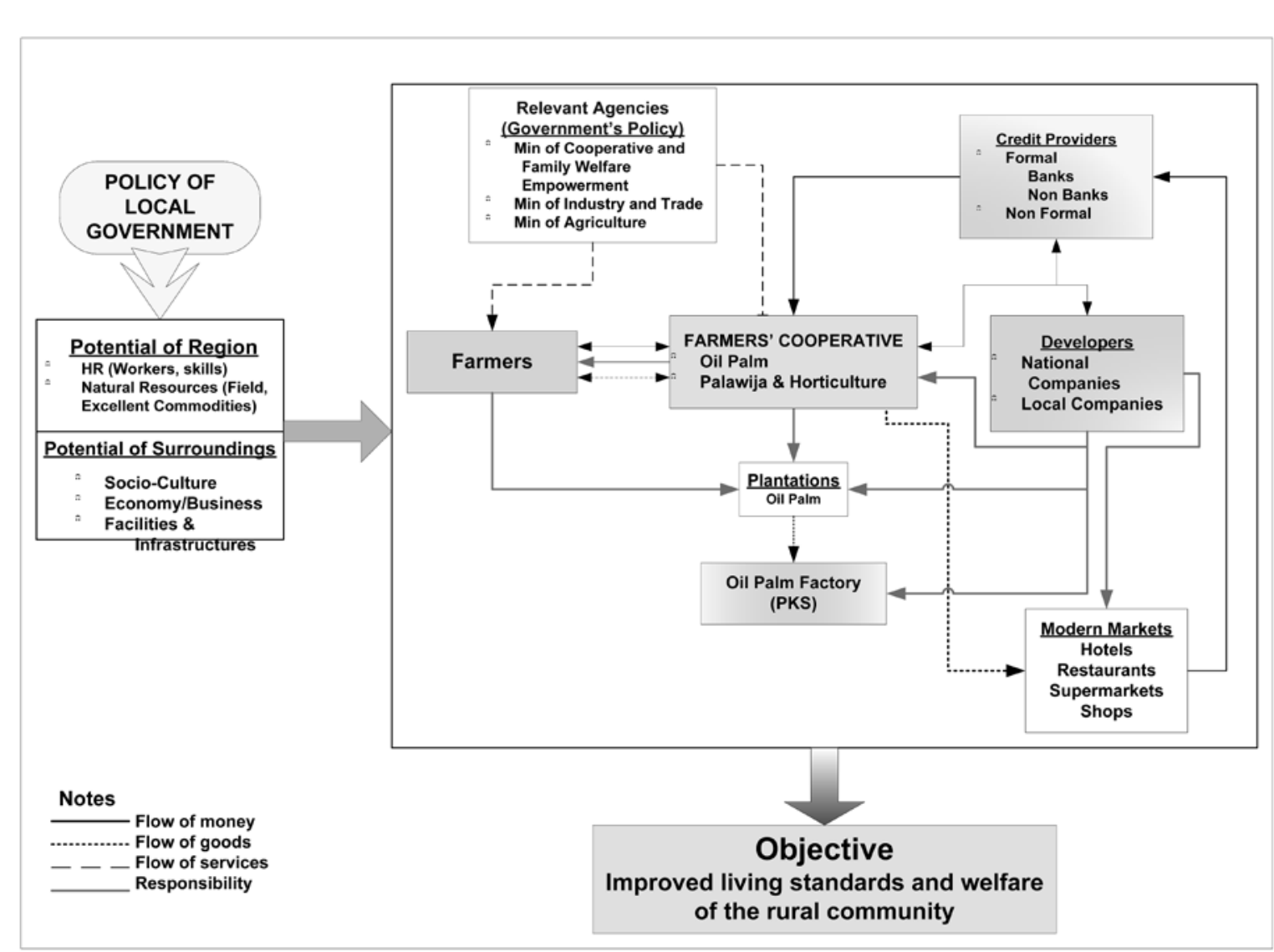

Figure 3. Model of Partnership in Development of the Community Plantation through

According Setiadi Wijaya (2002), a cooperative in the same way as a business institution is run. Nowadays, a cooperative does not reflect a form of modern business which is professionally managed and it even has an image that it is only suitable for the poor and does not require management. On the contrary, a cooperative is a business entity, so management is necessary to maintain its survival. If a cooperative wants to advance itself, it does no have any choice but to establish a partnership with other business entities which share its interests to be mutually beneficial. This business partnership is necessary to support the efforts to develop a cooperative.

\section{Developer (the Nucleus Company)}

A nucleus company which becomes a working partner of a cooperative is a privately/state-owned plantation companies or state-owned legal entities in Indonesia which according to the assessment is a business organization that must be managed 
of the government have sufficient ability in terms of funding, human resources and management to implement the function as a corporate partner. In the development of the community palm oil plantations with KPPA pattern, a nucleus company should carry out the following obligations, which include:

- The nucleus company which has been designated as a partner of a cooperative has to independently appoint consultants to carry out a feasibility study.

- The nucleus company which establishes partnership with a cooperative must make an agreement in writing which is acknowledge by the head of district. The Plantation Regional Office and the Cooperative Regiona Office in this district as the witnesses and as implementers of KKPA development must have a business license for cultivation and a business license for industry.

- The nucleus company establishes the plasma plantation in accordance with the operating instructions and physical standards as established by the Director General of Plantations cq. Plantation Provincial Office

- To collect the yields of palm oil plantation from the members at a reasonable price in accordance with the guidelines as set by the government which in this case is the Team for Assessment and Determination of Purchase Price of Palm Oil FFB which are harvested by the farmers.

- To assist the farmers in the repayment of credit by making deduction from the sale of FFB at a maximum of $30 \%$.

Models of the Management of Palm oil Plantations The purpose of the development of palm oil plantations is to improve the welfare of the rural communities (farmers). One of the indicators of welfare is an increase in the farmers' income. One source of their income is the proceeds from the agricultural activities, such as: palm oil plantations, supporting crops which consist of the palawija crops and the horticulture crops. In order that the farmers earn a decent income from cultivating crops, the business must be managed properly. For this purpose, various stakeholders should be involved, including: farmers, cooperatives, companies, financial institutions and relevant government agencies. To ensure that the system in the development of the community plantations is running as expected, the activity needs to be monitored by independent institutions, including, universities (research institutes, study centers), research and development agencies, or NGOs. For more details, the model of the management of community palm oil plantations can be seen in Figure 4.

The cooperative has an active role in managing the community plantations because the cooperative connects between the farmers and the partner companies. The cooperative plays the dual roles in the agricultural activities since it purchases FFB to be supplied to the palm oil factory and while at the same time it provides production facilities and agricultural tools which can support the activities of palm oil plantations. Playing those roles, the cooperative will receive two types of benefits which are essentially the benefits for its members. In addition, the cooperative serves as a connecting agency between its members and financial institutions, in which the cooperative can become a guarantor for credit from banks whenever the farmers need funds for their business development.

To perform its role as a farmers' organization, the cooperative must be fostered by the relevant agencies and the partner companies, which can be done by improving the quality of management of its administrators and managers, or carrying out other forms of development that support the cooperative's work program

The development of agribusiness which is combined with the development of the agribusiness cooperative will require a reorientation of services provided by the government. In the past the

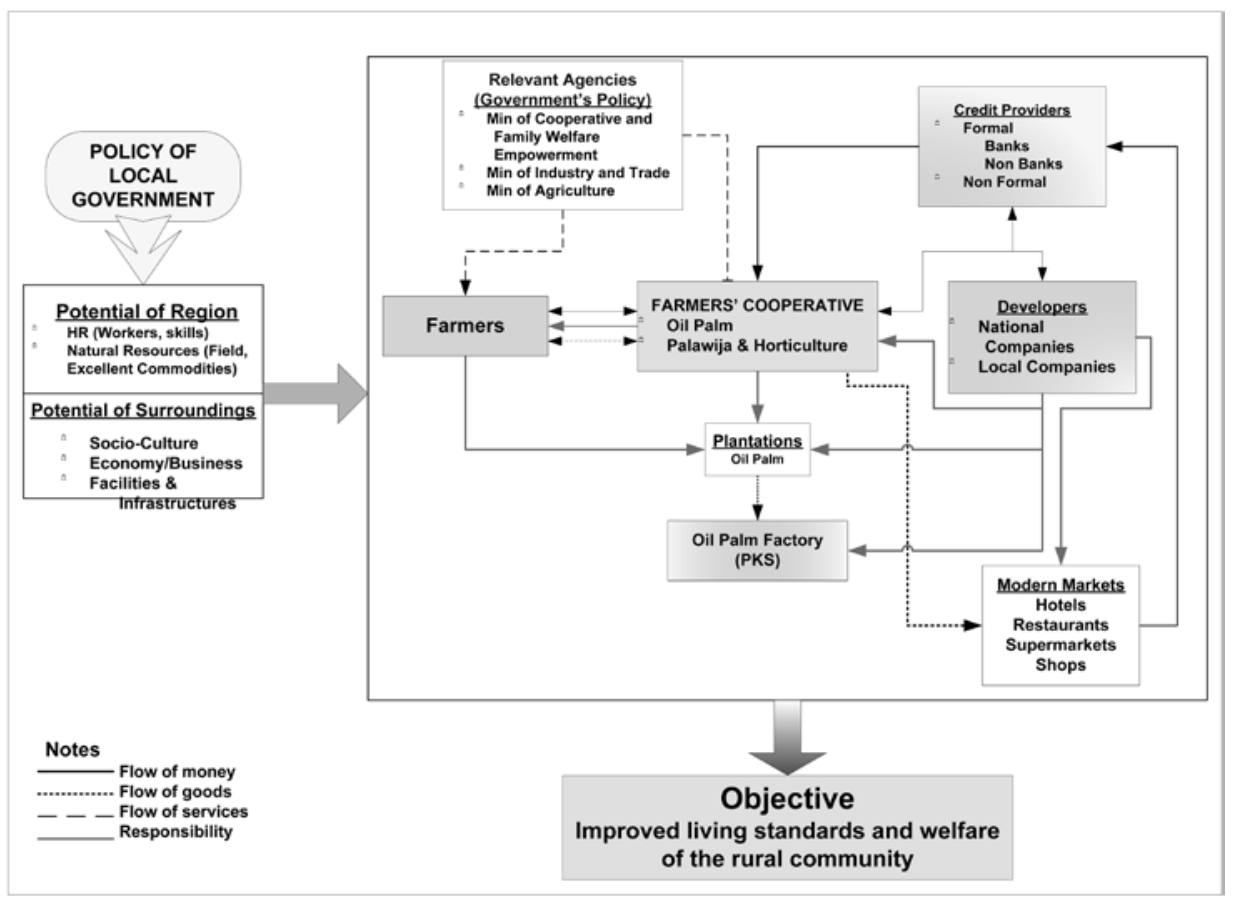

Figure 4. Partnership Model in the Management of Community Palm oil Plantations in Rural Areas (Modified from Almasdi Syahza, 2009a)

agricultural credit system was only aimed at the agricultural activities, whereas in the future it needs to be also oriented to the non-agricultural activities. Similarly, in the past the extension work on agriculture was only focused on the agro-technical aspects, but later it needs to be expanded into providing extension work on agribusiness, or even it needs to change a role into an agribusiness consultant. Overall, the development of agribusiness requires integrative government's policy.

If the development of agriculture with the agribusiness approach which is accompanied with the development of agribusiness cooperatives is successful, it will not only remove farmers from the vicious cycle of the socio-economy, but at the same time it will also build a competitive national agribusiness. The reasons include: First, this approach which is combined with the development of the agribusiness cooperative can eliminate the paradox of productivity at the agricultural level, so it can help to remove the farmers from the vicious cycle of socio-economy. Any increase in productivity will be accompanied with an increase in income, whether derived from the added value of the agriculture and nonagriculture products through the cooperative; Second, the establishment of the agribusines cooperative in non-agricultural activities which have institutional ties with the farmers, amon cooperatives, and with the private companies and the state-owned enterprises, will able to eliminate the problem of transmission prices and multiple margins. Thus, the price of agricultural facilitie paid by the farmers will be less expensive, stimulating the expansion of agricultural activities, and the price of the final agribusiness products as a whole can be less expensive at the consume level (encouraging an increased consumption). In addition, the consistency and continuity of the quality of the final products can be assured. Overall, this will enable agribusiness products to compete in the international markets; Third, the eliminatio of problem of price transmission will integrate the farmers' economy and the non-farmers' economy. The increase in non-farmers' income will increase consumption of end products of agro-industry, which is generally elastic to the changes in income. This will increase the farmers' income 
through the cooperative; and fourth, because the added value of the non-agriculture products partly lies in the hands of the farmers' cooperative, the cooperative can accelerate the accumulation of capital that will be used to make the farmers and their cooperatives independent.

\section{MANAGERIAL IMPLICATINS}

\section{Model Scheme of Small Scale Palm Oil Factory}

Agribusiness with palm oil as a commodity

integrates the activities of cultivation/agriculture and of the palm oil factory or mill into a type of ownership which emphasizes the principle of joint ownership of the agricultural business and processing factory by farmers. The running of the factory or the mill should take into account the production capacity of each business activity the availability of land (which is increasingly limited), the availability of the processing industry (particularly the production capacity), and the amount of investment.

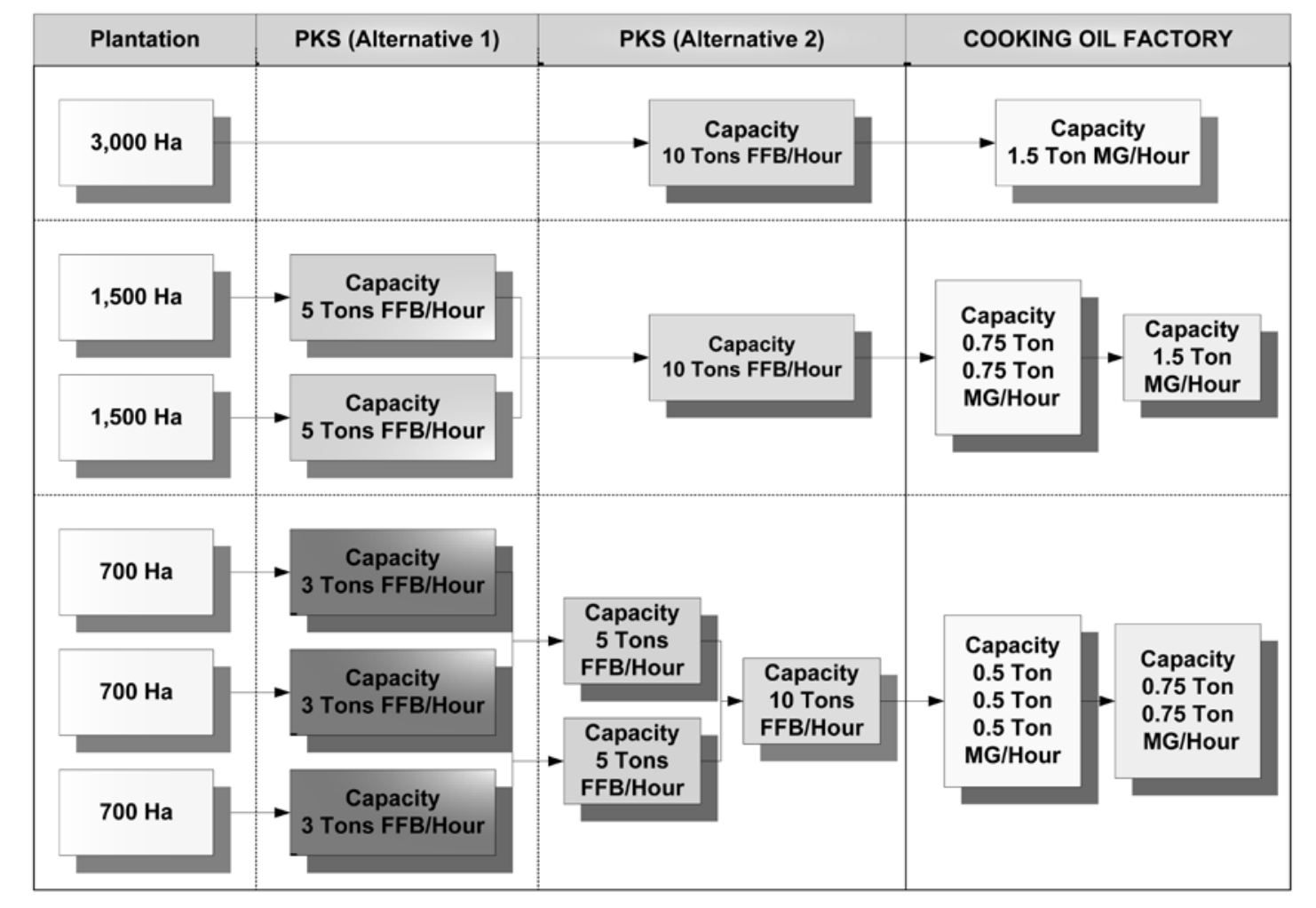

Figure 5. Conceptual Scheme of Palm oil Factory (PKS) and Small Scale Cooking Oil Factory in Rural Areas (Almasdi Syahza, 2004)

Since the palm oil plantations which are cultivated by the self-supporting farmers are located in scattered areas (not in one area like the plasma plantations), the development of an palm oil factory should be adjusted to size of the plantations which will supply the factory in a particular area. The appropriate ratio between the size of the area and the palm oil factory and and the palm oil factory is presented in Figure 5

A cooking oil factory can be designed up to the capacity of 1.5 tons MGS / Hour or 7,200 tons MGS / year, with the assumption of 16 hour working hours/day, 25 days/month and 12 months/year (Figure 5). This palm oil factory is designed to purify CPO into palm oil and it is also equipped with the equipment for a fractionation process, so the resulting product is Refinery Bleaching Deodorizing Palm Olein (RBD Palm Olein) which is a cooking oil product with grade "A" quality.

186

\section{CONCLUSION}

The results of the research which was conducted in rural areas suggest that the development of palm oil plantations can improve the economy in rural areas. It will create the purchasing power in rural areas, which in turn increases the demand for goods which are needed by the community.

For the rural community, plantations have been an alternative to improve the family's economy, so their interest in the development of plantations remains high. Furthermore, the clearing for plantations requires land, and if it cannot be controlled by the policy makers, there will be conversion in land use in rural areas.

The activities of palm oil plantations in rural areas have two business patterns: the plasma pattern, which is known as PIR pattern by private companies or state-owned enterprises and the individual or self-supporting pattern by the community. The self-supporting farmers feel there a price distortion at the farmer level because the market for their palm oil products is not guaranteed. To prevent price distortion, the development of palm oil agribusiness in the future is designed in the form of partnership between the farmers and the developer, in which the farmers have a plot of palm oil plantation and have a share in the capital ownership of the palm oil factory. This concept emphasizes the principle of joint ownership with farmers of both the agricultural activities and the processing factory, which is managed by the farmers' cooperatives. The model is designed in the form of palm oil-based agroestate (ABK)

The design of ABK model in rural areas aims to ensure the certainty in the processing of fresh fruit bunches (FFB) produced by the participant farmer. The agroestate package will ensure price certainty of FFB at the level of farmers and provide multiple benefits to farmers, among other things: the certainty of collection and pricing of FFB; the dividends from ownership of the shares of the palm oil company by farmers; the distribution of net profits of the farmers' cooperative.

A plantation management model should be designed in accordance with the needs of the farmers and partners, both raw materials required by the palm oil factory and the production facilities and agricultural machinery by farmers. The linkage between the farmers and the partners in $\mathrm{ABK}$ model should be integrated by a farmers' cooperative and supported by financial institutions. The ABK model in rural areas should be planned in such a way as to give priority to the principle of mutual benefits. The development of agroestate should be designed to increase the income and welfare of rural communities. Institutions are designed in a working network based on the ability and professionalism of various actors in the business, namely the developers, industrial factors, settlements of farmers, active participant farmers, the managing business entity (BUP) or cooperatives, or management of the manager (agricultural activities, industrial factories), and financing institutions.

Since the palm oil plantations which are cultivated by individual farmers are located in scattered areas (not in one area like the plasma plantations) the development of an palm oil factory should be adjusted to size of the plantations which will supply the factory in a particular area.

Acknowledgment
This third-year Competence Grant for Research is funded by the Directorate General of Higher Education, Ministry of National Education, for fiscal year 2011 by virtue of the Agreement for the Implementation of Competence Grant for Research Number Dedication to the Community through the Research Institute of Universitas Riau which has provided opportunities and funding in the form of the third-year Competence Grant for Research. It is expected that the results of this research is useful for the development of science and the advancement of education in Indonesia. 
REFERENCES

Almasdi Syahza., 2003. Paradigma Baru: Pemasaran Produk Pertanian Berbasis Agribisnis di Daerah Riau, dalam Jurnal Ekonomi, Th. VIII/02/Juli/2003, PPD\&I Fakultas Ekonomi Universitas Tarumanagara, Jakarta.

-., 2004. Pemberdayaan Ekonomi Masyarakat Pedesaan Melalui Pengembangan Industri Hilir Berbasis Kelapa Sawit di Daerah Riau, dalam Jurnal Sosiohumaniora, Vol 6, No3 November 2004, Lembaga Penelitian Universitas Padjadjaran, Bandung.

-., 2005. Dampak Pembangunan Perkebunan Kelapa Sawit Terhadap Multiplier Effect Ekonomi Pedesaan di Daerah Riau, dalam Jurnal Ekonomi, Th. X/03/November/2005. Jakarta: PPD\&I Fakultas Ekonomi Universitas Tarumanagara.

-., 2007a. Model Pemberdayaan Masyarakat dalam Upaya Percepatan Pembangunan Ekonomi Pedesaan Berbasis Agribisnis di Daerah Riau, Penelitian Fundamental DP2M Direktorat Jenderal Pendidikan Tinggi Departemen Pendidikan Nasional, Jakarta.

-., 2007b. Percepatan Pemberdayaan Ekonmomi Masyarakat Pedesaan dengan Model Agroestate Berbasis Kelapa Sawit, dalam Jurnal Ekonomi, Th.XII/02/Juli/2007, PPD\&I Fakultas Ekonomi Universitas Tarumanagara, Jakarta.

-., 2006. Pembangunan Perkebunan Kelapa Sawit Dan Kesejahteraan Petani Di Daerah Riau, dalam Jurnal Sorot, Vol 1 No 2, Oktober 2006, Lembaga Penelitian Universitas Riau, Pekanbaru.

-., 2009a, Perumusan Model Pengentasan Kemiskinan Melalui Pemetaan Kelembagaan Ekonomi Berbasis Agribisnis Di Propinsi Riau, Penelitian Strategis Nasional DP2M Direktorat Jenderal Pendidikan Tinggi Departemen Pendidikan Nasional, Jakarta.

-., 2009b, Ekonomi Pembangunan Teori dan Kajian Empirik Pembangunan Pedesaan, Pusbangdik Universitas Riau, Pekanbaru.

--.., 2010, Kelapa Sawit: Dampaknya Terhadap Percepatan Pembangunan Ekonomi Pedesaan Di Daerah Riau (Penelitian Hibah Kompetensi Tahun II), DP2M Direktorat Jenderal Pendidikan Tinggi Departemen Pendidikan Nasional, Jakarta.

2011, Kelapa Sawit: Dampaknya Terhadap Percepatan Pembangunan Ekonomi Pedesaan Di Daerah Riau (Penelitian Hibah Kompetensi Tahun III), DP2M Direktorat Jenderal Pendidikan Tinggi Departemen Pendidikan Nasional, Jakarta.

Bustanul Arifin., 2001. Spektrum Kebijakan Pertanian Indonesia, Erlangga, Jakarta.

Dinas Perkebunan Propinsi Riau, 2011, Buku Saku Dinas Perkebunan Propinsi Riau, Pemerintah Propinsi Riau, Pekanbaru.

Ginanjar Kartasasmita., 1996, Pembangunan untuk Rakyat, Memadukan Pertumbuhan dan Pemerataan, Cides, Jakarta.

Gumbira Sa'id, E. dan L. Febriyanti. 2005. Prospek dan Tantangan Agribisnis Indonesia. Economic Review Journal 200. (On-line). http://209.85.135.104/search?q=cache:3-EDCELftAoJ:www.bni.co.id/Document/16\%2520Agribisnis.pdf+Economic+ Re view+Jurnal,+Gumbira\&hl=id\&ct=clnk\&cd=1\&gl=id, diakses 11 Mei 2010.

Setiadi Wijaya, N.H., 2002, Membangun Koperasi dari Mimpi Buruknya, dalam Jurnal Usahawan Indonesia, N0. 07/TH. XXXI Juli 2002, Lembaga Manajemen FE UI, Jakarta.

Todaro, Michael P, 2006. Pembangunan Ekonomi, Erlangga, Jakarta.

Yuswar Zainal Basri., 2003, Pemberdayaan Ekonomi Masyarakat Pedesaan, dalam Usahawan Indonesia No 03/TH.XXXII Maret 2003, Lembaga Manajemen FE-UI, Jakarta. 